\title{
The true state of your health
}

Ruth Bastable, Sarah Rann and Vinny Barker are, according to Ruth, 'Divine Creatures', the sort of tosh one expects from a Cambridgeshire sisterhood of GP and Nurse trainers. More details will

unfold in coming months.

Rbbastable@aol.com

sfrann@doctors.org.uk

vinny.barker@nhs.net

Jeff Clark is a GP principal in Woodside Health Centre in Bristol. He is a member of the South Bristol GP Trainers' Group. Though interested in matters

philosophical he can still pride himself in a new bathroom.

jeffclarkuk@googlemail.com

Peter Davies is a GP from Halifax and a member of RCGP UK Council. npgdavies@blueyonder.co.uk

In a recent column in the Times, Mike Fitzpatrick pointed out that there had been 150 cases of measles in Hackney summer past. See

http://www.timesonline.co.uk/tol/commen t/columnists/guest contributors/article23 64350.ece and note the responses. A flavour of our times.

fitz@easynet.co.uk

Debbie Wai is a Specialist Registrar in Clinical Radiology at Sandwell and West Birmingham Hospitals.

Mythily Katsaris is an Assistant Solicitor in the Corporate Department of Fladgate Fielder in London.

Rishi Singhal is a Specialist Registrar in General Surgery at the Queen Elizabeth Hospital, Birmingham.

waideb@hotmail.co.uk

And meanwhile, distraction activities are these still permissible? Does Good Medical Practice sanction covert surveillance of real-time cricket scores during real-time consultations? Ball by ball commentary in a small window on your computer? Presently the Test Series England via Sri Lanka, at

http://www.bbc.co.uk/blogs/tms/.

England, I predict, will be out-bowled and lose and I shall watch it covertly as lives collapse around me and I accelerate statin dosage. Sympathetically.

A better suggestion still is long distance yacht racing.

See http://www.alexthomsonracing.com/ home.asp and

http://www.barcelonaworldrace.com/. Ten to 20 boats, all of roughly the same design (60 feet long) and you race them around the planet for 25000 or so miles, takes about 3 months. The anorak bit is takes about 3 months. The anorak bit less, complete with 3-D animation, audio, video and meteo (as they say in France). All building up to Edition 5 of the Vende Globe, the pinnacle of single-handed global racing starting November 2008 http://www.vendeeglobe.org/en/ What pillar of the international general practice community would do well in that? Nominations welcome.

Call for columnists - the inestimable Jeffreys is on sabbatical. There is a vacancy. One sample column, 700 words, two outline columns, to me. Alec Logan: aleclogan@dial.pipex.com
In an interview in last month's Men's Health magazine, celebrity chef Nigel Slater (of whose writings and recipes I am a long-standing admirer) was asked, if the prime minister were to ring, what advice he would give him for improving the nation's diet. His response: 'a free health check for everyone. The sort of really comprehensive annual one I pay a thousand quid for! Seeing the true state of your health in black and white would make anyone think more seriously about what they put in their mouth'.

We can expect to see them soon in our surgeries. Even though BUPA is now offering a range of health assessments, labelled like models in a car showroom - 'classic', 'premier' - starting from $£ 300$ (including 31 tests and 1 hour with a doctor), many of our patients will feel that the NHS should offer the same range of dubious screening tests now considered appropriate by many employers.

Of course, many of these tests, including blood glucose and cholesterol, liver function tests, screening for Helicobacter, Chlamydia and prostate specific antigen are now available - at exorbitant prices - over the counter in high street pharmacies and supermarkets. Purchasers of these tests are coming in already, to discuss the significance of the results and for advice on how to live with the consequences.

But why settle for revelations about your health in dull monochrome, when you can have a total body MRI scan and visualise your internal anatomy in glorious Technicolor? With discounted prices now falling towards $£ 1000$, this is the gift of the season - leaving blood pressure and blood glucose monitoring devices in the old millennium.

The central assumption underlying the vogue for screening tests is that the 'true state of your health' can be revealed by biochemical study of the fluids or by imaging the tissues of the body. For Slater, this information provides the basis for healthy eating, the highest form of ethical virtue recognised in contemporary society.

Now that health has replaced heaven (in either terrestrial or celestial forms) as the goal of human existence, health has been reduced to the anatomical and physiological functions of the human organism. The highest aspiration of the modern individual is biological survival, complemented by the state of bovine contentment celebrated as 'happiness' by government advisers, a condition to be achieved by making healthy lifestyle choices, appropriately corrected by short courses of cognitive behaviourial therapy.

Yet, as the literary critic Terry Eagleton reminds us, for Aristotle a true state of health meant a 'flourishing life', not merely in terms of prolonging our bodily existence, but in terms of personal achievement. $^{2}$

What matters is not merely feeling good about ourselves, but living and acting well. Happiness is the result of human activity in the world, it is not just a state of mind, and even less mere animal fitness. Contrary to the solipsistic outlook reflected in the demand for screening tests, a true state of health has an inescapably social as well as an individual character.

The fetishism of the body in contemporary culture, expressed in cults of body enhancement as well as the narcissism of the complete checkup, is linked to a pervasive fear of disease and an ultimate terror of death. For Eagleton, these preoccupations reflect a 'fantasy of mastering the unmasterable, a disavowal of death, a refusal of the limit which is ourselves'. Though subjecting the body to a relentless regime of prevention and surveillance is unlikely to make much difference to the duration of our animal existence, it is certain to reduce the scope of our humanity (as well as imposing an unsustainable burden on our health services).

The quest to find the truth in the laboratory test tube or in the tomb of the MRI scanner meets its terminus in the 'pornographic meaninglessness of a corpse'. If the body is 'an inconvenient reminder of mortality', the dead body 'proclaims the secret of all matter, that it has no obvious relation to meaning'.?

\section{REFERENCES}

1. Slater N. Eating his words. London: Men's Health, 2007, 171-172.

2. Eagleton T. After theory. London: Allen Lane, 2003.

DOI: 10.3399/bjgp08X263974 